\title{
It's not about you: The negligible biographical information in Australian prime ministerial portraits
}

\section{Introduction: The epitome and the transient mood}

In November 1945, Mrs R. D. Berry of Walcha, New South Wales, wrote to Prime Minister Ben Chifley, offering to send a portrait she had painted of the late John Curtin for his consideration. Chifley directed the deputy secretary of the Prime Minister's Department, Frank McKenna, to tell her that he would 'not be in a position to express an opinion regarding its artistic merits' and to advise her to send the portrait to the chairman of the Commonwealth Arts Advisory Board, Gother V. F. Mann. Soon, however, McKenna had to write again to Mrs Berry to inform her that 'Mr Mann ... does not think an amateur without art education could produce the desired result' in a portrait of Curtin. Kindly but discouragingly, he told her that 'Mr Mann would be glad to report on your painting if he saw it, but he does not think it advisable to trouble you to send the painting to his office for that purpose.'

Whether or not it resembled Curtin, the principal difficulty would be the unlikelihood that a portrait by an amateur would express something of Curtin's character or essence. In an essay about the American portraitist John Singer Sargent, author Henry James suggested that the portraitist will attain the 'highest result' when he $[$ sic]:

sees deep into his subject, undergoes it, absorbs it, discovers in it new things that were not on the surface, becomes patient with it, and almost reverent, and, in short, elevates and humanizes the technical problem. ${ }^{2}$

\footnotetext{
1 'Portrait of Right Honourable John Curtin by Cav. A Dattilo-Rubbo 1941-1947', National Archives of Australia (NAA) A463, 1965/1998, item number 98614; 'Sir William Dargie', National Gallery of Australia, James Gleeson Oral History Collection, 27 November 1978, accessed 28 November 2020, nga.gov.au/research/gleeson/ artists/dargie-1.cfm.

2 Henry James, 'John S. Sargent', Harper's Magazine 75, no. 449-48 (October 1887): 683-91.
} 
In 1941, John Rothenstein, director of London's Tate Gallery, explained the difference between portraits by Joshua Reynolds and Thomas Gainsborough. Reynolds, he said, 'possessed the rare power of regarding his sitters with psychological insight ... [The] sitter's permanent characteristics are surely seized by Reynolds and given exalted expression, whereas Gainsborough reveals their most transient moods. The one painter gives a professional apotheosis, an epitome of a career, the other an intimate interpretation' ${ }^{3}$

Had Reynolds and Gainsborough both been in a position to tender their credentials in mid-September 1912, when Australia's new Commonwealth Art Advisory Board (CAAB) invited artists to make themselves known for consideration as painters of portraits to be commissioned by the Historic Memorials Committee (HMC), ${ }^{4}$ Reynolds might well have been the favoured man. Portraiture is 'a secular art that is about the present, or an aspect of the present, designated for future consumption, for a time when nobody will be able to compare the representation and the original'. ${ }^{5}$ In a national leader's portrait, it is surely the professional apotheosis, the epitome, that is to be desired over a picture of a person in the throes of a feeling that may pass, however interesting or affecting such a picture may be.

Biographers implicitly suggest the absence of 'rare power' or 'psychological insight' in any Australian prime ministerial portrait because they rarely mention these works. To take but a few of many examples, Sir John Bunting's teasingly titled R.G. Menzies: $A$ Portrait features a portrait by Ivor Hele on the cover, but Bunting refers to it only in a brief quotation from a previous biographer. ${ }^{6}$ Troy Bramston does not write of any portrait of Menzies in Robert Menzies: The Art of Politics. ${ }^{7}$ Jenny Hocking's twovolume biography of Gough Whitlam spans 1,000 pages, but its images comprise photographs only and it contains no reference to any painted portrait of Whitlam, not even that which won Clifton Pugh the Archibald Prize, and about which much could be said. ${ }^{8}$ Entries in the Australian Dictionary of Biography customarily conclude with a note as to where portraits of the person described may be found; rarely, if ever, in the body of the entry are these portraits adduced as evidence of any characteristic of the person under description. In turn, in her book on the artist

3 John Rothenstein, 'British Painting: A General View', Burlington Magazine for Connoisseurs 78, no. 455 (February 1941): 36-45.

4 Commonwealth of Australia Gazette, no. 59 (14 September 1912): 1580; Felicity Reaburn, 'The History of the Historic Memorials Committee', (1987-1988), Senate Finance and Public Administration Legislation CommitteeSupplementary Budget Estimates 2005-2006, Department of Parliamentary Services Answers to Questions on Notice, Attachment A (October 2005).

5 Marcia Pointon, Portrayal and the Search for Identity (London: Reaktion Books, 2013), 14-15.

6 Sir John Bunting, R.G. Menzies: A Portrait (North Sydney: Allen \& Unwin, 1988), 17. Bunting quotes Percy Joske.

7 Troy Bramston, Robert Menzies: The Art of Politics (Melbourne: Scribe, 2019). The 1960 sketch of Menzies by William Dobell is reproduced in the book between pages 182 and 183.

8 Jenny Hocking, Gough Whitlam: A Moment in History: The Biography, Vol. 1 (Melbourne: Miegunyah Press, 2008); Gough Whitlam: His Time: The Biography, Vol. 2 (Melbourne: Miegunyah Press, 2012). Hocking names Clifton Pugh three times among lists of Whitlam's supporters at various junctures, but does not mention his portrait of Whitlam. 
Frederick McCubbin, Ann Galbally mentions his fine portrait of Alfred Deakin only in a list of portraits McCubbin painted between 1901 and $1914 .{ }^{9}$ These examples, and many that follow, indicate that painted portraits of prime ministers are not only of negligible value to biographers, but of little interest to art historians. As painter Charles Conder suggested to Australian artist Tom Roberts, "Parliamentary Coves" are usually so beastly ugly' ${ }^{10}$

In this article, I consider portraits of various Australian prime ministers against the contrasting modalities of 'professional apotheosis' and 'intimate interpretation', seeking to dispel the widespread notion that a painted portrait can convey something about the feelings, experience or inner life of its subject. Series of political portraits exist for reasons other than memorialisation. A group of prime ministerial portraits both represents and buttresses state power, but is also driven by the common human impulse to collect a 'full set', and the idea of inspiring a perceived audience. I argue that biographers' inattention to painted portraits of their subjects indicates that they reveal little of significance.

\section{The rise of civic and political portraiture in Great Britain}

It is a cliché that the British brought their enthusiasm for portraits to their colonies. ${ }^{11}$ Portraits in England, as in the other mostly Christian capitalist states in which portraiture is practised, were not always expected to express character. Portraiture began there, as elsewhere, with paintings in which a likeness of the person paying the artist was inserted into a scene also including a holy entity (for example, The Withypool triptych, showing Mary, Joseph and Jesus with one Paul Withypoll, a merchant and parliamentarian). ${ }^{12}$ The sixteenth century yielded the familiar Tudor and Stuart portraits characterised by small, detailed, expressionless heads atop rigid, rich costumes. In the late sixteenth and early seventeenth centuries, a number of Dutch artists in England lent pictorial support to the mood spread by the new Protestant Church: 'a practical, dignified but decidedly undemonstrative view of greatness and public responsibility'. ${ }^{13}$

\footnotetext{
9 Ann Galbally, Frederick McCubbin (Richmond, Vic.: Hutchinson Group, 1981), 129-30.

10 Quoted in Helen Topliss, Tom Roberts 1856-1931: A Catalogue Raisonné, vol. 1 (Melbourne: Oxford University Press, 1985), 22.

11 Benjamin Robert Haydon said: 'Wherever the British settle, wherever they colonise, they carry and will ever carry trial by jury, horse-racing, and portrait painting.' Desmond Shawe-Taylor, The Georgians: Eighteenth Century Portraiture and Society (London: Barrie and Jenkins, 1990), 7.

12 'The Withypool Triptych [Antonio da Solario, 1514]', Bristol's Free Museums and Historic Houses, 11 December 2015, accessed 1 November 2020, www.bristolmuseums.org.uk/blog/collections/11-angels-from-our-collection/ attachment/withypool-triptych-k1394/.

13 Andrew Wilton, The Swagger Portrait: Grand Manner Portraiture in Britain from Van Dyck to Augustus John 1630-1930 (London: Tate Gallery, 1992), 15, 33, 76.
} 
The proliferation of portraits post-Reformation prompted art historian John Berger to caution scholars of the genre to consider not just the 'few extraordinary examples' but the 'endless' paintings of local notables in 'countless' provincial venues. ${ }^{14}$ The Australian prime ministerial portrait has its roots in a new, drab portrait species that appeared across England during the refashioning of agencies of authority in the second half of the sixteenth century; the individual civic portrait, depicting regional mayors and aldermen, enjoined to carry themselves in a 'sadd and wise manner', hidden under monochrome gowns and depicted against plain backdrops of black or brown. Robert Tittler explains that the tenor of these portraits is one of weight and dignity ... The jaws are often slack, mouths are closed and often grim. Brows tend to be furrowed, shoulders slightly stooped ... eyes lined with age, care and wisdom and marked as often as not by a hollow stare'. While painted bodies of aristocrats often emphasised 'the virility which was essential to their culture', portraits of mayors and aldermen focused 'not on loin or limb ... but on the head'. ${ }^{15}$ In Parliament House, Canberra, only in John Gorton's portrait by June Mendoza is there a hint of loin. Tittler suggests that civic portraits burgeoned in the attempt to reinvent 'Englishness' without reference to Catholicism, an effort towards the 'selective reconstruction of a collective memory in a particular community' postReformation. ${ }^{16}$ Similarly, the mayoral portrait was one of the many strategies employed to entrench an ideology of civilised Australian history in the nineteenth century. In reaction to the establishment of the HMC, an anonymous contributor to the Age in 1914 cautioned the committee to limit their range of portrait subjects to holders of only the most elevated office, citing the fun-robbed experience of attending a concert at the Melbourne Town Hall surrounded by many 'gloomy' and 'melancholy' portraits of past mayors 'who gaze in mournful regret and pose in stiff attitudes. ${ }^{17}$ Protestant ideals of respectability and responsibility underpinned the rise of civic portraiture in Australia, as they had in Britain.

Over time, political portraits were afforded their own institutions. The National Portrait Gallery, London (NPG London), opened in 1856, and was the first of its kind in the world. Holding many of Britain's historical portrait treasures, in recent decades the NPG London has acquired a number of exciting works in unfamiliar mediums, including DNA, frozen blood, manipulated light and stuffed vermin, by artists including Marc Quinn, Chris Levine, and Tim Noble and Sue Webster. ${ }^{18}$ Of its many portraits of British prime ministers, two are notable. John Singer Sargent's Arthur James Balfour, 1st Earl of Balfour (1908), acquired in a desperate contest

14 John Berger, 'The Changing View of Man in the Portrait', in John Berger, The Moment of Cubism and Other Essays (London: Weidenfeld and Nicolson, 1969), 42.

15 Robert Tittler, 'Civic Portraiture and Political Culture in English Provincial Towns, ca. 1560-1640', Journal of British Studies 37, no. 3 (1998): 306-29, doi.org/10.1086/386167.

16 Tittler, 'Civic Portraiture and Political Culture', 324.

17 Age (Melbourne), 2 January 1914, 4.

18 Works by each artist are searchable at National Portrait Gallery, London, www.npg.org.uk/collections/. 
with an American collector in 2002, was described at the time by a spokesperson for the institution as one of Sargent's most 'fluid and luscious' portraits. ${ }^{19}$ Years before, British writer and critic G. K. Chesterton had called it a portrait of 'a sad philosopher and a sad statesman', adding that it evokes feelings of 'sober truths about the English governing class, its wide and ruinous scepticism, its remaining pillars of responsibility and reason' ${ }^{20}$ By way of contrast, there is no hint of either responsibility or reason in Photo $O p$ (2007), a digital collage of Tony Blair created by activists kennardphillips that the gallery purchased in 2018 and placed in the institution's 'Reference Collection', holding objects providing 'an alternative and less reverential view' of sitters than 'more conventional portraits'. ${ }^{21}$ Applied to Photo $O p$, such anodyne adjectives are comical. Before its acquisition, the Guardian's art writer Jonathan Jones had written that the 'strange and devastatingly effective quality of [Photo $O p$ is that it] really does meld into a luridly believable scene. The collective unconscious accepts this picture as true'. ${ }^{22}$ This mendacious image of a still-working former leader resides in an institution that is a primary instrument of state authority. As the NPG London is government-sponsored, its current chief patron the Duchess of Cambridge, the image is comprehensively 'authorised'.

The National Portrait Gallery, Canberra (NPG Canberra), established in 1998, was modelled closely on its London precursor, and, to some extent, the National Portrait Gallery in Washington DC. Former NPG Canberra director Angus Trumble has described Washington's presidential 'Gallery of Honour' as 'in many ways [the staff's] biggest problem'. ${ }^{23}$ Art historian Sasha Grishin feels that it is advantageous that Australian prime ministers' portraits remain in parliament, 'a place where rotten pictures accompany rotten politics', and do not 'visually pollute' Canberra's National Portrait Gallery as they do Washington DC. ${ }^{24}$ Among the thousands of portraits in the Canberra collection there are no moulded body fluids, taxidermy

19 Angelique Chrisafis, 'Portrait of Balfour Stays in Britain', Guardian (London), 23 July 2002, accessed 22 March 2021, www.theguardian.com/uk/2002/jul/23/artsandhumanities.arts.

20 'Arthur James Balfour, 1st Earl of Balfour [John Singer Sargent, 1908]', National Portrait Gallery, London, accessed 22 March 2021, www.npg.org.uk/collections/search/portrait/mw61798/Arthur-James-Balfour-1st-Earlof-Balfour; G. K. Chesterton, 'The Royal Academy', Art Journal (1908): 162.

21 'Tony Blair ("Photo Op") [kennardphillips (Peter Kennard and Cat Phillipps), 2007]', National Portrait Gallery, London, accessed 13 November 2020, www.npg.org.uk/collections/search/portrait/mw293862/TonyBlair-Photo-Op?LinkID=mp163226\&role=art $\& \mathrm{rNo}=3$; 'Reference Collection', National Portrait Gallery, London, accessed 13 November 2020, www.npg.org.uk/collections/about/reference-collection/.

22 Jonathan Jones, 'The Tony Blair 'Selfie' Photo Op Will Have a Place in History', Guardian 16 October 2013, accessed 2 October, 2020, www.theguardian.com/artanddesign/2013/oct/15/tony-blair-selfie-photo-op-imperialwar-museum.

23 Jil Hogan, 'Portrait Gallery Paints a More Eclectic Picture, Says Director', Canberra Times, 17 March 2014, 5. 24 Sasha Grishin, 'How (Not) to Paint a Portrait', Grishin's Art Blog (GAB), no. 34, 29 October 2018, accessed 28 January, 2021, www.sashagrishin.com/blog/gab-34-grishins-art-blog-34. The establishment of the National Portrait Gallery, Canberra, is described in Sarah Engledow, 'The National Portrait Gallery and Its Collection', in Sarah Engledow and Andrew Sayers, The Companion (Canberra: National Portrait Gallery, 2008), 2-7; and Sarah Engledow, 'Uncommon Australians: The Vision of Gordon and Marilyn Darling', in Sarah Engledow, Joanna Gilmour and Angus Trumble, Uncommon Australians: The Vision of Gordon and Marilyn Darling (Canberra: National Portrait Gallery, 2015), 3-11. 
or human tissue samples, and it has no 'Reference Collection' in which desirable portraits too provocative for the primary collection might be squirrelled. Just as there is no Australian prime ministerial portrait that would need be acquired in an international battle, there are none as tendentious as the kennardphillips portrait in any Australian collection.

\section{The origins of Australian prime ministerial portraiture}

It is more than a century since one 'Gallery Boy' noted a decline in the quality of portraits by Australian artist Norman St Clair Carter, charging him with 'bringing his art down to the level of public taste, which is not much developed in any country, and is particularly backward in the matter of portrait work, in Australia'. ${ }^{25}$ (In 1922 Carter was praised not only for his capacity to paint 'mental power' but also, more faintly, for following 'well established traditions' and painting with 'sincerity'.) ${ }^{26}$ Despite artists', curators' and educators' most ingenious efforts, and notwithstanding well-publicised developments in art styles and mediums since the beginning of the twentieth century, even an intelligent Australian layperson's loose expectation of a portrait remains a realist head-and-shoulders or three-quarter length image of a human being, slightly smaller than life-sized, viewed from the front with face on show, painted in oils on canvas or linen. When the human being is a prime minister, governor-general or judge, this expectation is markedly tighter. Being leaders, they deserve no less, but being functionaries, they deserve no more.

Homogeneity in portraits of Australian prime ministers is attributable partly to recommendations to artists set down at the time of the establishment of the HMC in 1911-12, which have changed little to this day. The fact that the majority of Australia's 30 prime ministers have been Australian-born, middle-aged, tertiaryeducated men with experience in law or politics, representing electorates in either Victoria or New South Wales, ranging in age at the time of first taking office from 37 years to 67 years with an average age of 52 years, also helps explain the similarities between the works. ${ }^{27}$ More often than not, in speaking of portraits of Australian prime ministers we speak of realist paintings of seated blue-eyed white men in their 50s, wearing suits and ties, depicted more or less facing the (male) artist, unsmilingly, from a slightly elevated position at a distance of about 2.5 metres.

\footnotetext{
25 'Gallery Boy', 'Art Notes', Sunday Times (Sydney), 10 August 1919, 27.

26 'Mr Norman Carter', Sydney Morning Herald, 22 May 1922, 4.

27 Joy McCann, 'Traits and Trends of Australia’s Prime Ministers, 1901 to 2015: A Quick Guide', Parliament of Australia, updated 3 February 2016, accessed 18 September 2020, www.aph.gov.au/About_Parliament/ Parliamentary_Departments/Parliamentary_Library/pubs/rp/rp1516/Quick_Guides/AustPM.
} 
Not counting a shady avenue lined with bronze busts of prime ministers in the Ballarat Botanical Gardens, initiated by parliamentarian Colonel Crouch in $1939,{ }^{28}$ Australia has two principal repositories of painted, drawn and sculpted prime ministers' portraits and prime ministerial paraphernalia: Parliament House, Canberra, and NPG Canberra. Until recently, the old, provisional Parliament House was also home to many such works; it still holds a good deal of ephemera. This essay is mostly concerned with paintings of Australian prime ministers in the Historic Memorials Collection, displayed in Parliament House. ${ }^{29}$ This collection was conceived in communications between Alfred Deakin and Tom Roberts, who urged Deakin to act before it was too late to 'give the future anything that will show what you all were as men to look at'. ${ }^{30}$ Incidentally, while his oeuvre comprises truly excellent portraits, Tom Roberts was not destined to paint a prime ministereven Deakin. (The latter was portrayed by Frederick McCubbin during the period of his 'most brilliant' works - including a self-portrait said to disclose 'something of the artist's mind and soul'. ${ }^{11}$ Deakin's biographer Judith Brett, however, regards McCubbin's portrait as 'rather stiff', favouring one by a Bendigo art teacher, who, lacking the skill to paint the leader's 'mesmeric' eyes, portrayed him shading them with his hand.) $)^{32}$ By the time Australia had a prime minister, Roberts's great portraits were past; he had exhausted himself rendering 269 individual likenesses in his monumental painting of the opening of Australias first parliament, only to find, during 16 dispiriting years in London, that few were very interested in it. ${ }^{33}$

Deakin prompted the prime minister, Andrew Fisher, and soon a committee was established to consult on Historic Memorials of Representative Men. ${ }^{34}$ It comprised - and did at least until 2011-the prime minister, the president of the senate, the speaker of the House of Representatives, the vice-president of the Executive Council and the leaders of the Opposition in both houses. The CAAB was established in 1912 to provide advice on suitable artists and assess the completed works. In 1972 this function passed to the Australia Council. ${ }^{35}$ In recent years counsel has been provided by the Senior Curator at the NPG Canberra, but that

\footnotetext{
28 Herald (Melbourne), 3 June 1939, 6. Crouch, a significant contributor to the cultural life of Ballarat, had already funded the relocation of Adam Lindsay Gordon's cottage from the rear of Craig's Hotel to the gardens.

29 Parliament of Australia, 'Portraits of Australian Prime Ministers from the Historic Memorials Collection', accessed 19 October 2020, www.aph.gov.au/Visit_Parliament/Art/Online_Gallery/Portrait_Gallery.

30 Tom Roberts, letter to Alfred Deakin, 11 March 1910, NAA A2, 1912/2035.

31 'Frederick McCubbin, Self-portrait c.1908', in Anne Gray, Australian Portraits 1880-1960 (Canberra:

National Gallery of Australia, 2010), accessed 20 January 2021, nga.gov.au/portraits/.

32 Judith Brett, The Enigmatic Mr Deakin (Melbourne: Text Publishing, 2018), 412.

33 Topliss, Tom Roberts 1856-1931, 22-26.

34 'Historic Memorials. A Committee of Advice', Sun (Sydney), 30 December 1911, 7; 'Historic Memorials. The Federal Committee. First Meeting', Daily Telegraph (Sydney), 14 February 1912, 8; Kylie Scroope, 'Faithful Representations: 100 Years of the Historic Memorials Collection', Papers on Parliament no. 57 (February 2012), Parliament of Australia, accessed 26 January 2021, www.aph.gov.au/About_Parliament/Senate/Powers_practice_n_ procedures/ / / /link.aspx?_id=826A07FC8D214FC1BF37B5F82E3BEA60\&_z=z\#_ftn1.

35 John Gardiner-Garden, 'Commonwealth Arts Policy and Administration', Parliament of Australia, 7 May 2009, accessed 22 October 2020, www.aph.gov.au/About_Parliament/Parliamentary_Departments/Parliamentary_ Library/pubs/BN/0809/ArtsPolicy.
} 
position was abolished in 2019. A list of suitable painters for at least one recent prime minister's portrait was disregarded, the former prime minister's preference suggesting that 'Gallery Boy's' remarks are as apposite today as in the 1920s.

As soon as the HMC was established, there was waspish press discussion of who its 'Representative Men' should be, and what purpose the portraits would serve:

It is proposed to immortalise 'some' of Australia's greatest men who have been connected with Federation ... The proposal emanates from the Prime Minister, who seems to be afraid that their names and memories will be forgotten unless there is tangible evidence that they once existed ... in some Federal Dead House which might be built in the wildernesses of New South Wales. ${ }^{36}$

The first 18 portrait subjects, including five prime ministers, were chosen by August 1912, and within weeks an advertisement appeared in the Commonwealth of Australia Gazette inviting qualified portrait painters to tender their credentials to the CAAB. Most portraitists of the first 11 prime ministers trained at the National Gallery of Victoria School between 1872 and 1911; many links may be traced between them. One, William Beckwith McInnes, winner of five of the first six Archibald Prizes in the 1920s and two more in the 1930s, asserted:

English artists have said of us Australians that we are 'old-fashioned' ... Certainly we in Australia have not been bitten by Cubism or Futurism or any of the other 'isms' and fads current now on the other side. And I am glad of it ... I cannot think that a failure to adopt the latest tricks ... is any reflection upon the genuine expressive work of any man or company of men in Australia. ${ }^{37}$

The aforementioned Norman Carter is reported to have called 'contemporary art' a 'fungoid growth'. ${ }^{38}$

The second, long-term chair of the CAAB, G. V. F. Mann, visited Europe in the mid-1920s and appears to have attributed many artists' struggles to sell their works to the current 'freakish craze for splotches and blotches, miscalled art'. Mann suggested that the persons depicted for Australia's National Collection might be extended to navigators, pioneers and explorers closely identified with the early history of Australia. 'This collection is the nucleus of a national portrait gallery', he declared. ${ }^{39}$ Yet the prime ministerial portraits in the HMC were not absorbed into

\footnotetext{
36 'Australia’s Great Men', Brisbane Courier, 22 February 1912, 4.

37 W. Beckwith McInnes, 'Only My Palette and I', Herald (Melbourne), 24 January 1925, 13.

38 Frances Lindsay, 'Carter, Norman St Clair (1875-1963)', Australian Dictionary of Biography, National Centre of Biography, The Australian National University, adb.anu.edu.au/biography/carter-norman-st-clair-5525/ text9409, published first in hardcopy 1979, accessed 20 January 2021.

39 Frances Wong-See, 'The Commonwealth Art Advisory Board from 1912 to 1926: Its Role in the Australian Art World' (Hons thesis, Department of Art History, The Australian National University, 1991), 45. For Mann's views on modern art see, for example, 'Paintings and Sculpture', Age (Melbourne), 26 October 1926, 15; and 'Works of Art', Mail (Adelaide) 31 July 1926. See also 'The Portraits to be Painted', Mercury (Hobart), 16 August 1912, 6; Commonwealth of Australia Gazette, no. 59, 14 September 1912, 1580.
} 
the collections of either the National Gallery of Australia (as had also been suggested, from 1918) or the NPG Canberra. On the contrary: the ongoing HMC program freed the NPG Canberra from responsibility to commission or collect portraits of all Australian prime ministers. Nonetheless, it has disparate portraits, acquired more or less opportunistically, of 17 of them, including photographs that may not only serve to document the individuals' careers but significantly influence historical assessments of them. Only once in the 21-year history of the NPG Canberra have the prime ministers' portraits been displayed as a group. ${ }^{40}$

After parliament moved from Melbourne to Canberra in 1927, its central King's Hall housed the portraits of prime ministers commissioned and approved by the HMC. ${ }^{41}$ So many busts and paintings were brought to the building that there was insufficient space to install them all, but many were on display. The Telegraph's critic mentioned the remarkable 'semblance of life' of a bust of George Reid, made in 1915-16 when Reid was around 70, by Charles Web Gilbert. ${ }^{42}$ Along with an exquisitely sensitive head of Stanley Bruce, made in 1939 by the remarkable Australian Barbara Tribe, Gilbert's Reid remains the outstanding sculpture of an Australian prime minister. ${ }^{43}$ From 1998 to 2008, when the NPG Canberra occupied part of what was then called Old Parliament House, many prime ministerial portraits were still in King's Hall. In counterpoint, in 2001 the NPG displayed Martin Wilson's Fuzzy Prime Ministers, a unique collection of bright tufted woollen portrait rugs of 25 Australian prime ministers. Cultural critic and administrator Leo Schofield judged them 'serious works of art by a serious artist'; the artist himself said he hoped the collection would 'unite the country like no other rugs have before'. ${ }^{44}$ Rebranded MOAD (Museum of Australian Democracy), Old Parliament House exhibited Bidjara artist Michael Cook's Through My Eyes (2010), an important series of 27 portraits of recognisable prime ministerial faces overlaid with features drawn from photographs of Australian Aboriginal subjects, in $2014 .{ }^{45}$ It has recently displayed onetoeight (2017), a series

\footnotetext{
40 These include David Moore's Robert Menzies, Lancaster House, London (1956) and President Johnson and Prime Minister Holt at Canberra Airport 1966; Mervyn Bishop's Prime Minister Gough Whitlam pours sand into the hand of traditional landowner Vincent Lingiari 1975; Roger Scott's Malcolm Fraser, Randwick Racecourse 1975 and Sue Ford's Discussion between Bob Hawke and Galarrwuy Yunupingu, Burunga Festival, Northern Territory 1988. See works in the focus exhibition Primed, curated and described by the author, National Portrait Gallery, Canberra, accessed 16 September 2020, www.portrait.gov.au/content/some-prime-ministers.

41 Scroope, 'Faithful Representations'.

42 'The National Art Collection at Canberra', Daily Telegraph (Sydney), 14 December 1927, 8. While dated c. 1900 by the National Gallery of Australia, in the collection of which it resides, the Reid bust can be dated accurately from 'Bust of Sir George Reid', Sun (Sydney), 1 December 1915, 5; 'Sir George Reid', Sydney Morning Herald, 26 January 1916, 12; and 'The Life That Breathes in Marble', Herald (Melbourne), 14 February 1916, 1.

43 'Plans Busts of Australians', Daily News (Perth), 18 May 1939, 11.

44 Martin Wilson, Fuzzy Prime Ministers of Australia, National Portrait Gallery, Canberra, accessed 17 August 2020, www.portrait.gov.au/exhibitions/fuzzy-prime-ministers-of-australia-2001.

45 'Michael Cook: Through My Eyes', Andrew Baker Art Dealer, accessed 28 January 2021, www.andrew-baker. com/Michael\%20Cook_Through\%20My\%20Eyes.pdf.
} 
of appropriated, reworked portraits of the earliest prime ministers by Alison Alder. ${ }^{46}$ In between, in 2015, portraits were 'cleared from Kings Hall'. ${ }^{47}$ Interesting and dynamic portraits of prime ministers including Bob Hawke, Paul Keating and John Gorton remain in the MOAD collection, but are not regularly displayed. ${ }^{48}$

\section{Portraits and the revelation of character}

There is a long background to the idea that individual works within a series of portraits can reveal the differences between people who have occupied a particular role. English portraits in the seventeenth and eighteenth centuries both reflected and fostered the development of a cognitive distinction between a public persona, having to do with the sum of duties or offices held, and a private being, comprising something unique and immutable. ${ }^{49}$ As portrait conventions evolved from the seventeenth century onward, each public position had its 'accepted qualities and its acceptable limit of discrepancy' on canvas; an idiosyncratic treatment of a monarch or pope was far more acceptable than one of a person of lower rank with a job. ${ }^{50}$ Godfrey Kneller, working in England from the late 1670s, fitted the zeitgeist in presenting men and women 'devoid of glamour, evidently worthy, capable and honourable'. Emphasising both polite and political virtues, his art was 'a function of civic pride, and drew its justification from the need to reinforce civic values'. Yet the 'relaxed pose and conversational air' of one of his famed portraits of Charles II creates a new ambiguity: 'are we to respond to the presentation of the King or to the presence of the man?'51 (Portraits of the Australian prime ministers present a similar quandary.) Between the late 1690s and early 1720s, Kneller completed a set of more than 40 portraits of huge-haired Whig Protestants associated with the 'KitCat Club' including Britain's (and the world's) first prime minister, Robert Walpole. The Kit-Cat paintings represent an important moment in British portraiture as a uniform group of pictures of men with a conscious project to shape English national identity. Kneller's portraits, emanating 'civility', were an effective image platform for the famous affiliates. ${ }^{52}$

\footnotetext{
46 'onetoeight-Australia's First Prime Ministers. Solo Exhibition by Alison Alder', The Curators' Department, www.thecuratorsdepartment.com/alison-alder-one-to-eight.

47 Libby Stewart, 'Hawke and Keating Portraits Find a Permanent Home', Museum of Australian Democracy, Canberra, 27 February 2017, accessed 1 January 2021, www.moadoph.gov.au/blog/hawke-and-keating-portraits-finda-permanent-home/\#.

48 For more on this, see Stewart, 'Hawke and Keating Portraits Find a Permanent Home'.

49 Geoff Baldwin, 'Individual and Self in the Late Renaissance', Historical Journal 44, no. 2 (2001): 341-64, doi. org/10.1017/S0018246X01001637.

50 Berger, 'The Changing View of Man in the Portrait', 43.

51 Wilton, Swagger Portrait, 33, 96.

52 Philip Carter, 'Kit-Cat Club', Oxford Dictionary of National Biography, 22 September 2005, accessed 20 December 2020, www.oxforddnb.com/view/10.1093/ref:odnb/9780198614128.001.0001/odnb-9780198614128-e-73609.
} 
The Romantic period of the late eighteenth and early nineteenth centuries gave rise to the 'personality cult', a 'fascination with the particular qualities, idiosyncrasies and actions of a celebrated individual'. ${ }^{33}$ One of the principal proponents of the NPG London - the first government-sponsored portrait gallery in the world-was a cultural authority with an inalienable belief in the inseparability of portraits and biography: Thomas Carlyle. ${ }^{54}$ Carlyle grew up in the Romantic period but remained a force in British intellectual life for much of the Victorian era. From the 1830s he was increasingly convinced of the need for heroic leaders, notoriously proposing in his On Heroes, Hero-Worship and the Heroic in History that 'the history of what man has accomplished in this world, is at the bottom the history of the Great Men who have worked here.$^{55}$ His interest in portraiture was intense, not as an art genre but as a way into an authentic understanding of a human being; Julian North writes of his conception and practice of biography 'as, itself, a form of portraiture' ${ }^{56}$ Carlyle defined the 'authentic portrait' as a likeness made in the presence of the living subject by an artist with the ability to see his subject truly (more than a century after his death, this idea informed the collection policy of the NPG Canberra, which has acquired very few portraits made posthumously). With a fervent interest in human spiritual experience, he tended to trust the authentic portrait over accreted historical accounts. He wrote:

Often I have found a Portrait superior in real instruction to half-a-dozen written 'Biographies,' as Biographies are written; - or rather, let me say, I have found that the Portrait was as a small lighted candle by which the Biographies could for the first time be read, and some human interpretation be made of them. ${ }^{57}$

He suspected, for instance, that dry scholars had misled him about Henry VIII, as viewing Holbein's portrait he wondered 'is there not a jolly ringing laugh in him; and on the whole a good deal of fire, insight, generosity ... in the inner man?' ${ }^{58}$ North comments tartly that 'Carlyle's emotional and spiritual investment in portraiture's capacity to bring the sitter to life was far from unique amongst his contemporaries, but it was remarkable for its wilful attempt to bury scepticism' ${ }^{59}$

In 1945, when the idea of Britishness called for inspiring reinforcement, 40 of Kneller's Kit-Cat portraits were acquired by the NPG London. Author Lord Killanin saw in the better examples 'an effort to probe deeper than the mere visual aspect of the sitter as Lely and Van Dyck had done ... we begin to perceive [an] effort to

\footnotetext{
53 Shearer West, Portraiture (Oxford: Oxford University Press, 2004), 29.

54 Julian North, 'Portraying Presence: Thomas Carlyle, Portraiture, and Biography', Victorian Literature and Culture 43, no. 3 (2015): 465 - 88, doi.org/10.1017/S1060150315000030.

55 Thomas Carlyle, On Heroes, Hero-Worship and the Heroic in History (London: Chapman and Hall, 1840), 3.

56 North, 'Portraying Presence', 470.

57 Thomas Carlyle, letter to David Laing, 3 May 1854, Carlyle Letters Online, accessed 11 December 2020, clo.dev.cdhsc.org/volume/29/lt-18540503-TC-DL-01?term=David\%20laing.

58 North, 'Portraying Portraiture', 482.

59 North, 'Portraying Portraiture', 468.
} 
comprehend character'. Certainly, Killanin perceived much in Kneller's portraits of writers: 'There is the witty Congreve, the intellectual Dryden, the humorous Steele and the bitter Pope. His portraits tell, in the clear and simple strokes of the brush, as much of their character as one obtains in reading their diaries.' ${ }^{60}$ To this day, some painters and their sitters perpetuate similar notions. In a recent interview the London-based Australian portraitist Ralph Heimans said that he needs to 'try to breathe life into a figure. It's not just a superficial thing of how they look. It's really how they move, how they feel, how they think'. Even one of the most intelligent of his sitters told the interviewer that the subject of a Heimans portrait is 'not just seen in physical form but is revealed to be a composite of influences as a person with depth'. ${ }^{61}$

Such fallacious ideas became entrenched as portrait painters from the 1850s onwards faced a strong threat to their livelihoods: photography. John Berger suggests that artists and their circles fanned popular doubt of the camera's biographical authority by inventing 'mysterious, metaphysical qualities with which to prove that what the painted portrait offered was incomparable. Only a man, not a machine ... could interpret the soul of a sitter. An artist dealt with the sitter's destiny: the camera with mere light and shade'. Berger asserts that this 'claims for painted portraits a psychological insight which ninety-nine percent of them totally lack'. ${ }^{62}$ The mythology is so pervasive, however, that gallery staff will attest it is not unusual for an Australian visitor to our NPG Canberra to be disappointed-and even to infer some institutional disrespect-if any person they admire is represented in a photograph rather than a painting.

\section{'Conveying interiority': Different portraits of Stanley Bruce}

In the well-known correspondence between Richard Casey and Stanley Bruce is a reference to Casey's visit to Madame Tussauds, London, in May 1928. There, he saw Bruce portrayed life-sized in wax. Describing the experience as 'horrifying', Casey predicted his friend's shabby effigy would be mistaken for 'a wide range of popular celebrities varying from Mussolini ... to the late President of the Mexican Republic'. ${ }^{63}$ Early the following year, he wrote to Bruce: 'I see that you have agreed

60 Lord Killanin, Sir Godfrey Kneller and His Times, 1646-1723: Being a Review of English Portraiture of the Period (London: BT Batsford Ltd, 1948), 36. The book contains a remarkable fold-out 'Diagram showing Sir Godfrey Kneller in relation to the development of English portrait painting'.

61 Bevan Shields, 'Portrait Royalty', Sydney Morning Herald, 30-31 January 2021, 'Spectrum', 8-9.

62 Berger, 'The Changing View of Man in the Portrait', 41-42.

63 W. J. Hudson and Jane North, eds, My Dear P.M.: R.G. Casey's Letters to S.M. Bruce, 1924-1929 (Canberra: Australian Government Printing Service, 1980), letter dated 17 May 1928, 352. 'Bruce, Hughes, Melba: Mme Tussaud's New Exhibition: World Celebrities Included: Horrors Chamber Still Charms', Evening News (Sydney), 19 March 1927, 6. Various workers' papers compared Bruce to Mussolini in the early 1920s, but not because of his appearance. 
to the Bruce Toby Jug being sold to the public. I inquired of the potters about it and got two of them. I think they have turned out very well indeed. If you want any I can get them and send them out. ${ }^{64}$ Madam Tussauds, London, with storage facilities at many locations, regretfully reports inability to find any record of the fate-or current whereabouts — of either the Bruce waxwork, or that of William Morris Hughes (commonly referred to by Bruce as 'Little Hughes') that stood, too, in its display of Colonial Premiers in 1928-29. ${ }^{65}$ The jug to which Casey refers, monochrome, with the stylised face of Bruce on its prow, was one of a numbered limited-edition series made at Surrey's Ashtead Pottery, established in 1923 to provide employment for disabled ex-servicemen. ${ }^{66}$ Number 1 of the 500 Bruce character jugs is in the collection of the NPG Canberra, its full provenance, exasperatingly, unknown.

No one would expect to learn anything of the character of Bruce from studying his costumed dummy, or, despite its generic name, the 'character jug' that incorporates his face (although we can infer a little about Casey's intimacy with Bruce, and certain assumptions the two men shared about dress, class, nationality and taste from Casey's few words). Charlotte Townsend-Gault advances the idea that the difference between an effigy and a portrait is that the latter relies on 'conveying interiority'. ${ }^{67}$ The usefulness of this distinction can be tested by comparison of various representations of Bruce. William McInnes's 'sad statesman' profile portrait of him in the HMC recalls Tittler's description of portraits of men of 'sadd and wise manner' against plain backdrops of black or brown. Its sombre palette is relieved only by delicate flesh tones and flashes of white with a glint of gold. The curve of the sitter's back is reprised in the chair arm. His long fingers are relaxed, his nails gleam discreetly. Heavy silk tassels balance the composition. With its exceptional quality of stillness, its sitter the very model of composure, the work is a good example of a portrait that might be said to 'convey interiority'. Indeed, soon after it was painted, it was deemed 'a striking and searching revelation of the man' ${ }^{68}$ Striking it may be; but while those who approach the portrait knowing something of Bruce's background and personality may find either their admiration of his ways or their mistrust of his politico-social milieu confirmed, no amount of searching the painting will reveal anything more about Bruce than will searching the Ashtead jug (which actually has an interior). The mystique of the 'searching revelation' is punctured by a photograph of Bruce sitting on a platform as McInnes goes about his job in

64 Hudson and North, My Dear P.M., letter dated 31 January 1929, 451.

65 Madam Tussauds Guest Experience Team, emails to author, 21 September 2020 and 23 September 2020.

66 'Exhibition of Ashtead Pottery', The Times (London), 1 April 1925, 19; Marion Edwards, 'Helping the Disabled: the Ashtead Pottery', Surrey in the Great War: A County Remembers, 20 February 2017, accessed 28 July 2020, www.surreyinthegreatwar.org.uk/story/helping-the-disabled-the-ashtead-pottery/.

67 Charlotte Townsend-Gault, 'Symbolic Facades: Official Portraits in British Institutions since 1920', Art History 11, no. 4 (December 1988): 512, doi.org/10.1111/j.1467-8365.1988.tb00321.x.

68 'Prominent Personalities: WB McInnes', Table Talk (Melbourne), 11 November 1926, 17. 
his Alphington studio in May $1925 .{ }^{69}$ All the painting can reveal is that McInnes chose to paint Bruce's patrician profile, and asked him to look at a point across the room. The most reliable thing the portrait can tell us is that we are primed to interpret a 'faraway' gaze as indicative of introspection. Neither of two very different biographers of Bruce mentions it. ${ }^{70}$

\section{An 'incisively observant' portraitist paints William McMahon}

Between 1950 and 1958 the handsome artist Ivor Hele, who painted more works on commission than any other Australian portraitist, had 17 works exhibited in the Archibald Prize and was victorious five times. In 1954 he won for his portrait of Robert Menzies, a man who, according to biographer Troy Bramston, 'even looked prime ministerial' for reasons including his height and weight. ${ }^{71}$ Hele's last portrait sitter was Malcolm Fraser. In between Menzies and Fraser he painted a prime minister shorter and lighter than either of them: William McMahon, described by Menzies as a 'little brute. ${ }^{72}$ In Tiberius with a Telephone, Patrick Mullins compares McMahon to a third big prime minister, suggesting that the electoral contest between McMahon and Gough Whitlam had as much to do with their appearance as their policies: 'He was short where Whitlam was tall; thin where Whitlam was broad-chested. He was faint-voiced where Whitlam's [voice] was sure; bald where Whitlam sported a full head of hair. Abuzz and flighty where Whitlam was deliberate, McMahon simply could not help but appear a pitiably small figure by comparison.' He alludes to cartoonists' drawings of McMahon 'as a gnome-like figure, short and weedy, a bigeared, ageing dwarf'. ${ }^{73}$

Curator Jane Hylton writes that as Ivor Hele was 'incisively observant' his sitters were 'confident they would be portrayed as dignified and strong ... and that some aspect of their closely observed personality would enliven the completed picture'. ${ }^{74}$ Yet a glance through Tiberius with a Telephone illustrates the difficulties this expert painter faced in rendering either a professional apotheosis or an intimate interpretation of this inconsistent subject:

69 'Happy Voyagers: Feeding the Workless: Mr Bruce's Portrait', Herald (Melbourne), 27 May 1925, 18. The portrait was hung in Queen's Hall in October 1926. 'Mr Bruce Takes His Place', Herald (Melbourne), 21 October $1926,6$.

70 Ina Mary Cumpston, Lord Bruce of Melbourne (Melbourne: Longman Cheshire, 1989); David Lee, Stanley Melbourne Bruce: Australian Internationalist (London: Continuum, 2010).

71 Bramston, Robert Menzies, 5.

72 Bramston, Robert Menzies, 302.

73 Patrick Mullins, Tiberius with a Telephone: The Life and Stories of William McMahon (Melbourne: Scribe, 2018), 554-56.

74 Jane Hylton, Ivor Hele: The Productive Artist (Kent Town, SA: Wakefield Press, 2002), 10. 
Averse to late nights, favouring a good night's sleep, disdainful of conversations without meaning or purpose ... an immensely charming man ... At dinners and at parties, in meetings, and indeed in idle conversations, McMahon could be witty and lively, humorous and quick. 'He is a charming and generous host and a gracious guest and is surprisingly attractive to women,' Don Chipp would later say ... 'He could be charming, but he was always trying too hard,' journalist Mungo MacCallum ... said later.

Mullins writes that to Alan Ramsey, 'McMahon's failings, inconsistencies and lies were simply a matter of character: "That was just the manner of the bloke". 'Laurie Oakes said he was a 'pathological liar' who bordered on diseased; but his staff members did not think so. ${ }^{75}$ What aspect of this 'closely observed' personality was Hele to render?

Hele tackled McMahon's portrait over several sittings at his studio in Aldinga, South Australia, towards the end of July 1972. McMahon said he found the artist 'a delightful companion, interesting and amusing'. Notwithstanding that one of McMahon's staffers said he had never seen him sit still for more than half an hour, the prime minister said: 'I regard myself as a very self-disciplined person ... If I know I have to do something I resign myself to it. ${ }^{76}$ The finished portrait was hung in Parliament House, Canberra, on Friday 1 June 1973, and pictured in the Canberra Times the following day beneath a report of the fatal stabbing of a shearers' cook 80 miles north of Hay the previous night - a reminder that often, articles about new official portraits are juxtaposed with more interesting news. (In August 1909 a report of the unveiling of a portrait of one of Manly's mayors ran alongside an account of the departure from Redfern railway station of the Chinese illusionist Chung Ling Soo, with assembled conjurors producing flags from thin air to wave as the train left the platform.) $)^{77}$ Tiberius with a Telephone is 776 pages long, but neither features nor mentions Hele's portrait of McMahon. ${ }^{78}$ It can only be concluded that Mullins wrote nothing about McMahon's portrait because it added nothing to his understanding of his subject.

\section{Practical challenges of prime ministerial portraiture}

Prime ministerial portraits are affected by a variety of professional and practical challenges having nothing to do with the characters of their subjects. The file in the National Archives of Australia pertaining to William Dargie's portrait of Arthur

\footnotetext{
Mullins, Tiberius with a Telephone, 472, 311.

76 'PM Poses for Ivor Hele', Canberra Times, 26 July 1972, 1.

77 Evening News (Sydney), 7 August 1909, 5.

78 Mullins, Tiberius with a Telephone.
} 
Fadden-prime minister for a mere 39 days between the giants Menzies and Curtin—reveals little about Fadden, but speaks of the frustrations of the professional portraitist. Commissioned in 1941, Dargie soon began work, but progress was delayed for various reasons. In January 1943 the CAAB inspected the portrait and asked Dargie to 'effect several alterations'. A year later the HMC decided to accept it, subject to his being asked to 'consider the remodelling of the forehead on the leftside and ... the avoidance of the pinched appearance of the mouth'. On reinspection in October 1945 the HMC requested a completely new portrait. In July 1946 this was accepted, 'subject to slight alterations, principally to the fingers and eyes'. The portrait was formally accepted in September 1947. Yet with his right arm drastically foreshortened and his hand in the foreground of the work, Fadden seems trapped in perpetuity too close to the picture plane, awkwardly cramped between artist and canvas. Dargie won the Archibald Prize eight times between 1941 and 1956, but it is conceivable that his trials with Fadden's portrait gave rise to advice in his $O n$ Painting a Portrait:

Imagine you have begun your painting and after a certain length of time you realise that one arm, and, of course, the hand at the end of the arm, is pointing almost directly at you. Now any painter will find it very difficult to paint a hand and arm in this position: the foreshortening is abrupt, and the appearance of the hand is directly opposed to our natural idea of what we might call the 'lengthiness' of the hand when the wrist and fingers are at right-angles to the line of vision. The almost inevitable result will be that the hand and arm in the painting will look stumpy and unnatural ... This, then, is the first hint for the amateur painter beginning a portrait: see that your subject is arranged in such a way that there is no abrupt foreshortening in either the arms, hands, or legs. The simplest way to achieve this result, of course, if to have your subject seated sideways on to the painter, so that the full length of the near arm and leg is clearly visible. ${ }^{79}$

The foreshortened Fadden appears very unsophisticated compared to the languid and long-lashed Bruce, prudently rendered by McInnes side-on.

The HMC set of Australian prime ministerial portraits was imperilled in the mid1940s, as both Curtin and Chifley_each customarily ranked among Australia’s outstanding, or inspiring, prime ministers ${ }^{80}$ — died before portrait projects commenced. Chifley was painted from photographs by Archibald Colquhoun in 1952. ${ }^{81}$ The National Archives' file on the portrait of John Curtin runs to 134 pages. Letters therein reveal that in March 1943 one Frank Carter wrote straight to Curtin asking to paint his portrait, acknowledging that his direct approach was

\footnotetext{
79 William Dargie, On Painting a Portrait (London: The Artist Publishing Co. Ltd, 1957), 50-52.

80 'Historical Rankings of Prime Ministers of Australia', Wikipedia, accessed 10 January 2021, en.wikipedia. org/wiki/Historical_rankings_of_prime_ministers_of_Australia; Malcolm Mackerras, 'Ranking Australia’s Prime Ministers', Sydney Morning Herald, 25 June 2010, accessed 28 January 2021, www.smh.com.au/national/rankingaustralias-prime-ministers-20100624-z3bn.html.

81 'Chifley's Portrait for Canberra', Sunday Herald (Sydney), 7 December 1952, 5.
} 
unusual but explaining he was 'fortified in some measure by the striking success which has resulted from your own direct methods'. We have read of the offer of Mrs Berry. Ivor Hele, however, was the CAAB's choice. Initially, there was doubt over whether Captain Hele could be paid for a commission while on military service; Curtin put off sitting to him before travelling to England in 1944. There was some hope that Hele could set to in the autumn of 1945, but a sitting did not ensue; later, Hele refused the CAAB's request to paint Curtin from a photograph. Will Rowell, commissioned to paint Curtin in March 1946, died in August that year. Ultimately, Curtin was painted from a photograph by the Sydney artist Antonio Dattilo Rubbo. The resulting portrait was acquired along with Joshua Smith's characteristically disquieting rendering of Frank Forde, who appears to be snooping through papers on someone else's desk. Cavaliere Rubbo's portrait was minimally successful. According to the Age, Curtin's features were there, but his 'character' was not; the painted man, a 'cold ascetic', was 'scarcely recognisable as the sensitive emotional imaginative man who led Australia through its darkest hours' ${ }^{82}$

\section{Portraits to inspire: The professional apotheosis versus the intimate interpretation}

Portraits exist for various reasons other than to 'give the future anything that will show what you all were as men to look at', in Tom Roberts's words. The idea that portraits of heroes, dutiful citizens or the eminent are able to inspire or edify a viewer dates to the late sixteenth century or before. ${ }^{83}$ Thomas Carlyle envisaged the NPG London as a place where 'unconsciously but very veritably, the better parts of the soul of all might worship'. ${ }^{84}$ Marcia Pointon notes the gratification of the trustees of that institution when tidy working-class lads, 'charity children' and 'those belonging to the humblest classes' visited. ${ }^{85}$ Faith in the capacity of portraits to spur the viewer to achievement apparently underlies the comments of a reviewer of John Singer Sargent's 1917 portrait of Woodrow Wilson:

[T] he expression is one of thoughtful contemplation rather than attention. It is dignified, simple and extremely reticent ... It is the portrait of a scholar, a man of thought rather than action, and of a tired man at that ... One cannot but feel a shade of disappointment. ${ }^{86}$

82 'News of the Day: Notables in Oils', Age (Melbourne), 9 October 1947, 2.

83 West, Portraiture, 25.

84 North, 'Portraying Portraiture', 470.

85 Marcia Pointon, Hanging the Head: Portraiture and Social Formation in Eighteenth-Century England (New Haven and London: Yale University Press, 1993), 234.

86 'The Sargent Portrait of the President', American Magazine of Art 9, no. 4 (1918): 162, accessed 19 August 2020, www.jstor.org/stable/23936083. 
In 2008 the Guardian's visual arts critic, Jonathan Jones, wrote about a work in the collection of the Parliament of the United Kingdom: Tony Blair MP (2007) by Philip Oliver Hale. Hale painted Blair from an elevated perspective, looking across an implied interior in an apparently moody way. (Subverting the notion of the portraitist's X-ray gaze, the artist said he was 'lucky' that Blair had things other than his portrait to worry about; 'he didn't perform, and I didn't divine'.) Jones observed that while the portrait was 'honest' and had 'gravitas', Blair looked 'knackered' and 'fed up' in it. ${ }^{87}$ The two critics' reactions, nearly 100 years apart, raise the question of desirable qualities in a portrait of a leader. I suggest that 'dignity', 'simplicity', 'honesty' and 'gravitas' are characteristics of a 'professional apotheosis' portrait, while a weary or exasperated appearance may conduce to an 'intimate interpretation'. Cherie Blair, for her part, said at the time of the unveiling that the subject of Hale's portrait did not look like the man her husband was 'today'—post-prime ministership.

The intimate interpretations of Wilson and Blair contrast with an example of an energetic 'apotheosis' portrait in the Australian Historic Memorials Collection: Alfred Deakin's by Frederick McCubbin. In 1914-15 McCubbin created a painted man whose bright eyes and slight smile bespeak energy and curiosity; his forward step implies purpose and a 'man of action'. By contrast, in early October 1914 the real Deakin saw himself as 'so small, so superficial, so shadowy, so little even reflected of the man I once was' ${ }^{88}$ Upon its assimilation into the HMC in March 1915, the Argus commented 'Mr Deakin's portrait is undoubtedly good, though it is hardly the Mr Deakin of today' ${ }^{89}$ The epitome/transient mood dichotomy may be expressed as a question: on what day should a prime minister be portrayed?

\section{Contrasting, contemporaneous views of Joseph Cook}

The wall of prime ministerial portraits in Canberra's Parliament House is a logical place for school groups to gather and be informed that many of the Australian prime ministers inched towards the top job from impecunious childhoods in small country towns and working-class suburbs. Joseph Cook is outstanding among the Australian prime ministers whose childhood was not easeful. Born in an English mining town, he started work as a pit boy at nine, returning to support his family when he was 13, driving horses, oiling machinery and hewing at the coalface (Cook actually was a 'little digger'). He taught himself auditing and bookkeeping and grew into a Primitive Methodist, with 'no interest in sport, and little sense of humour.

\footnotetext{
87 'Tony Blair MP [Philip Oliver Hale, 2007]', ART UK, accessed 2 February 2021, artuk.org/discover/ artworks/tony-blair-mp-213888/view_as/grid/search/venue:parliamentary-art-collection-7391--works_auto:blair/ page/1; Mark Brown, 'New Portrait of “Knackered” Blair to Hang at Westminster', Guardian (London), 24 April 2008, accessed 17 January 2021, www.theguardian.com/politics/2008/apr/24/tonyblair.artnews.

88 Brett, Enigmatic Mr Deakin, 414.

89 'Federal Picture Gallery', Argus (Melbourne), 15 March 1915, 11.
} 
He never touched alcohol, and he detested gambling and tobacco. He ... was a poor and unwilling dancer. He disliked travel and preferred to spend his holidays working at home. He enjoyed singing, but only hymns'. ${ }^{90}$

Biographer Frank Crowley described Cook as 'hard-working, physically tireless and shrewd'. ${ }^{1}$ However, Cook's Historic Memorials portrait, unusual in the display (along with William McInnes's portrait of Scullin and Vincent Fantauzzo's of Julia Gillard) in that the subject faces the viewer at close range with no hands visible, is a 'tired-man' painting. Norman Carter was commissioned to paint him in 1916. By that time Cook was minister for the navy; in 1917 he became deputy prime minister. Carter was busy himself, teaching at Sydney Tech and in demand for portraits. Records show that the artist made two attempts at Cook before a gentle, almost tender 'oil sketch' was accepted by the HMC in May 1921. The painted Cook's pointed beard and moustache, a soft pale grey, are nattily trimmed, the moustache tips upturned. But neither natty nor puissant does he look. With his eyebrows slightly drawn together, his darkened eyes downcast, the painted Cook looks weary, distant, a little lost. The portrait could well be read as an intimate interpretation of the toll taken by the execution of public duty during a tragic and tumultuous period of history, but it is not an image likely to inspire a young person to a life in public service.

At 87, Norman Carter recalled the juggling act of concentrating on a canvas while observing and listening to a sitter:

It [can take] a fairly long time to do a picture-you've got to study a man, get his character ... Usually, I used to get him to talk ... But the difficulty is dealing with certain people. Some sit too still and the result is you cannot get them as they are. Then you strike some fortunate subject that draws out the man-for instance politicians, particularly, you'd speak about their enemies and you can't stop them from talking. In studying for a portrait of a man you have to draw the man himself out, not merely do it to a certain principle ... You gradually get to know that man, separated from all the rest of the people; find out what he is.

The artist recalls 'There was one sitter I had that wouldn't talk_-and people's first thing they said when they saw the picture was "it looks as though he didn't talk". I said "He didn't—he wouldn't!" 92 Was it Cook? Or did Cook 'sit too still' for Carter

90 John Murdoch, Sir Joe: A Biographical Sketch of Joseph Cook (Stoke on Trent, UK: A Silverdale Historical Publication, 1979), 1-3.

91 F. K. Crowley, 'Cook, Sir Joseph (1860-1947)', Australian Dictionary of Biography, National Centre of Biography, The Australian National University, adb.anu.edu.au/biography/cook-sir-joseph-5763/text9765, published first in hardcopy 1981, accessed online 27 March 2021.

92 Norman St Clair Carter interviewed by Hazel de Berg, Hazel de Berg collection [sound recording], 1962, ORAL TRC 1/28, National Library of Australia, accessed 13 November 2020, nla.gov.au/nla.obj-214272137. 
to 'get him as he was'? Certainly few would suspect that the man in Carter's portrait, soon to be appointed Australia's High Commissioner to the United Kingdom, would 'immensely [enjoy] London's social round'. ${ }^{93}$

While the Carter portrait was in train, Joseph Cook and William Morris Hughes were both painted by the Scottish artist James Guthrie in preparation for his whopping group portrait Statesmen of World War I (1930). ${ }^{94}$ (This painting, in the NPG London, is readily confused with one in the Imperial War Museum, London, The Signing of Peace in the Hall of Mirrors, Versailles 28 June 1919 (1919) by William Orpen in which Hughes also features.) Sixteen of the men in Guthrie's painting posed for him individually and his oil studies were acquired by the National Galleries of Scotland in September $1920 .{ }^{95}$ So it is that the National Portrait Gallery, Edinburgh, now holds the luminous oil sketches, made in 1919, ${ }^{96}$ of Hughes and Cook. The latter shows a pale-eyed man in a shaft of light, his slight squint conducing to a determined, visionary look, his crow's-feet suggesting a very faint smile (did we not know, from reading, that he did not, we might infer Cook had a sense of humour). ${ }^{97}$ His dark moustache dangles into his uneven, paler beard. His elbow rests on the back of his chair; his hand hangs loosely yet the closed fingers convey an impression of resolve. Appearing to be looking at the ceiling cornice on the other side of the room, alone, he seems to be listening. (In Guthrie's finished Statesmen of World War I (1930), he seems, as do others, to be listening to Arthur Balfour.) Perhaps Cook simply had a better time with Guthrie than he did with Carter; but Cook's future biographers would do well to note that the man in the portrait refined and reworked by Carter in Australia between 1916 and 1921 looks older and more dispirited than the one painted by Guthrie in 1919 in a study for a work representing an imaginary scene taking place in World War I but not completed until 1930.

\section{Branding, power and the impulse to collect}

Series or sets of portraits of mayors, directors and prime ministers are not mere evidence that various people have existed and held jobs. To a significant degree, they exist for purposes of state or corporate branding and assertion of power and continuity. The expectation of portraits in sites of control such as private schools, courts and houses of parliament is ideological; we hardly see them, let alone

\footnotetext{
93 Crowley, 'Cook, Sir Joseph'.

94 'Statesmen of World War I [Sir James Guthrie, 1924-30]', National Portrait Gallery, London, accessed 27 March 2021, www.npg.org.uk/collections/search/portrait/mw00301/Statesmen-of-World-War-I; 'The Signing of Peace in the Hall of Mirrors, Versailles, 28 June 1919 [William Orpen, 1919]', Imperial War Museum, accessed 18 August 2020, www.iwm.org.uk/collections/item/object/20780 ; 'Sir James Guthrie: William Morris Hughes, 1862 1952. Prime Minister of Australia', National Galleries Scotland, accessed 18 August 2020, www.nationalgalleries. org/art-and-artists/2772/william-morris-hughes-1862-1952-prime-minister-australia.

95 'Empire War Statesmen', Times (London), 8 September 1920, 8.

96 Hughes and Cook left England in early July 1919. 'Mr Hughes's Return', Times (London), 7 July 1919, 12.

97 Francis Crowley twice uses the word 'humourless' in his Australian Dictionary of Biography entry on Cook.
} 
wonder why they exist, or what their subjects were like to be around. Art historian Charlotte Townsend-Gault refers acidly to the bland physiognomies of subjects of contemporary portraits of 'patent mediocrity' in the 'dining halls of the universities and the Inns of Court, the head offices of the banks, the reception rooms of the Royal Society, the grand staircase of the Royal College of Physicians, the boardrooms of Times Newspapers and United Biscuits'. She argues that institutional portrait collections, typically exhibiting very little stylistic deviation (as in the case of the Australian prime ministerial portraits), amount to a Foucaultian 'code' imposing discipline and normalisation. ${ }^{98}$

Portrait sets are also impelled by an impulse common to many children and some adults to collect - expressed at its utmost by dedicated collectors with defined goals, progress towards which will bring pleasure and fulfilment of which will bolster selfesteem. (Some Australian prime ministers have been represented on 'collectables' of a domestic nature: the National Portrait Gallery, London, has Ardath 'Empire Personalities' tobacco cards representing Stanley Bruce and Joseph Lyons, ${ }^{99}$ and in the author's possession is a miniature portrait of W. M. Hughes on silk, issued with purchase of BDV Cigarettes as part of its series 'Great War Leaders' in 1916.) Compared with the proclamation of power and normativity, amassing a complete set seems like an ingenuous driver; yet there is also a palliative purpose. It has been noted that, often, adult collectors maintain that their hoards represent an artistic and historic legacy that will benefit 'future generations ... [imbuing] collecting with a heightened sense of purpose and destiny'. ${ }^{100}$

Once announced and commenced, the accumulation of a public collection cannot halt without management of public expectations. On the website of the Sydney Town Hall is a one-minute voice recording about the many portraits on display in the building. A full 10 seconds of the audio are given over to explaining why not all mayors are represented. ${ }^{101}$ Visitor services staff know that an incomplete set is dissatisfying, and possibly even alarming, to the public. Questions will be asked, as they are about the commissioned John Howard and Janette Howard (2000) by Josonia Palaitis in the National Portrait Gallery, Canberra, posited as the first in a series of portraits of Australian prime ministers and their life partners, but also the last such image created, for various personal and practical reasons. ${ }^{102}$ Although the current prime minister is not expected to be represented within their term, the set of prime ministerial portraits in Parliament House, Canberra, is currently well out of

\footnotetext{
98 Townsend-Gault, 'Symbolic Facades', 511-12.

99 'Empire Personalities: Cigarette Cards Issued by Ardath, 1937', National Portrait Gallery, London, accessed 20 August 2020, www.npg.org.uk/collections/search/set?set=672\&wPage=1.

100 William D. McIntosh and Brandon Schmeichel, 'Collectors and Collecting: A Social Psychological Perspective', Leisure Sciences 26, no. 1 (Jan-Mar 2004): 87, doi.org/10.1080/01490400490272639.

101 'North Portraits', Sydney Town Hall, accessed 18 January 2020, www.sydneytownhall.com.au/discover-learn/ openmi-tours/north-portraits/.

102 'John Howard and Janette Howard', National Portrait Gallery, Canberra, accessed 28 March 2021, www. portrait.gov.au/content/some-prime-ministers.
} 
date: portraits of Kevin Rudd, Tony Abbott and Malcolm Turnbull are outstanding. It is to be hoped that they will materialise soon. Non-fulfilment of the collection may imply broader political and cultural inertia, indecisiveness and obliviousness to tradition, possibly giving rise to anxiety on the part of those few concerned with certain cultural practices.

\section{Rejected: George Reid and W. M. Hughes}

Looming large in such discussion as exists of Australias prime ministerial portraits is a painting of Sir George Reid undertaken in 1913. By that time Reid had already been the subject of countless Australian caricatures; a fine plaster medallion by Nelson Illingworth that, according to the Sunday Times, his friends were using to adorn their homes and his enemies a target for pistol practice; and a 5-inch 'paperweight or ornament' of Lithgow iron manufactured in commercial quantity in $1910 .{ }^{103}$ (Among a good handful of portraits of Australian leaders held overseas are photographs of Reid held in the Library of Congress, Washington. ${ }^{104}$ In August 1912 the new CAAB recommended the creation of portraits of Edmund Barton, Alfred Deakin and Reid, by then living in Britain as Australia's first high commissioner. ${ }^{105}$ The HMC commissioned Reid's portrait from George Washington Lambert, formerly of Sydney but by then working among the most exciting painters in Edwardian London. The fate of the ensuing work is notoriously indicative of the CAAB's conservative, narrow ambitions for prime ministerial portraiture in Australia.

In the collection of Sydney's Museum of Applied Arts and Sciences is a pencil drawing, indicating Lambert's attention to the distinctive elements of Reid's face, conceivably made in preparation for the portrait. ${ }^{106}$ The finished painting is stark and sharpfocused. Appearing to have wedged himself into a low-backed 'Savonarola' chair, Reid looks towards the viewer with bespectacled head slightly cocked. His hands, hanging loosely over the tips of the chair arms, and his splayed legs, terminating in shiny shoes, look small compared to his large torso. Nearby are a curtain and

103 Evening News (Sydney), 12 January 1910, 8. The statuette was on sale at the mainstream store Farmer Bros. 'George Reid Paperweight', National Portrait Gallery, Canberra, accessed 19 October 2020, www.portrait.gov.au/ portraits/2006.81/george-reid-paperweight/; 'Sir George Reid [Nelson Illingworth, c. 1895]', National Portrait Gallery, Canberra, accessed 19 October 2020, www.portrait.gov.au/portraits/2016.34/sir-george-reid.

104 Martha Sear, 'George Reid: A Journey through Three Parliaments', transcript of a talk given 13 August 2008, National Museum of Australia, accessed 20 January 2021, www.nma.gov.au/audio/behind-the-scenes-australianjourneys-series/transcripts/george-reid-a-journey-through-three-parliaments; Bain News Service, 'Sir Geo. Reid, ca. 1910', Library of Congress, accessed 26 January 2021, www.loc.gov/item/2014690723/; Harris \& Ewing, 'Reid, Sir George. Former Australian Premier. Right, with James Oyster, Commr. of D.C., 1912', Library of Congress, accessed 26 January 2021, www.loc.gov/item/2016864016/. The Library of Congress also holds photographs of Scullin and Deakin.

105 'Historic Memorials Matters for Reference to, and Consideration by, Historic Memorials Committee', NAA A457, B508/7. Wong-See, 'The Commonwealth Art Advisory Board', 16.

106 'Portrait Drawing of Sir George Reid by George Lambert', 1909-18, Museum of Applied Arts and Sciences, Sydney, accessed 8 November 2020, ma.as/157407. 
a table on which lie two books, sandwiching a dangling document. Art historian Anne Gray writes that the work was 'unexceptional' among portraits by respected contemporary British artists; British critics thought it combined 'good portraiture, accomplished artistry and a subtle sense of humour'; Sir George was 'delighted' with the painting; and Bertram Mackennal, the CAAB's agent in London, approved of it. However, in the body of existing Australian portraiture it was anomalous. ${ }^{107}$

The HMC, which Gray calls 'a cautious and conservative body with a preference for tonalism' and a propensity to return works for revision, felt that the oil portrait of Reid lacked dignity. ${ }^{108}$ Gray reports that the Bookfellow of 14 December 1914 judged: 'Sir George Reid deserved better treatment than some of the others; if he has got worse, that fits the evil fortune which dogs nearly all Government attempts to patronise art. ${ }^{109}$ In early 1915 the Sydney Evening News reported that the HMC felt it inadvisable, for the present, to hang the portrait publicly as 'it has met with much criticism, which is likely to bring discredit upon the artist and the board'. ${ }^{110}$ Melbourne's Punch was unsurprised that London's Morning Post picked up on the committee's 'grotesque' treatment of the artist. Calling Lambert a great painter and deeming the portrait of Reid 'easily the finest of the portraits the orders of the Memorials Committee have produced', Punch's correspondent argued that Reid, a man of 'enormous disproportions', could not be made picturesque, for 'he is in some sense a national caricature, and admits the fact every time he gets on his heels before a crowd'. ${ }^{111}$

George Lambert's portrait of Reid was accepted by the HMC, and it hung briefly in Parliament House, Melbourne, but by early 1925 it had been replaced by a portrait of Reid commissioned from John Longstaff. ${ }^{112}$ Lambert's 1927 portrait of William Morris Hughes fared scarcely better. Having rejected a portrait commissioned from Norman Carter, Hughes sat to a Bendigo artist, Marion Jones, of whose portrait he said, 'It's not justice I require, but mercy, and I've found it'; but the HMC did not acquire Jones's effort. ${ }^{113}$ Hughes sat to Lambert 12 times in February 1927, but repudiated the finished work. ${ }^{114}$ In 1930, Lambert died, aged 56. In 1947 Hughes conceded to the display of Carter's painting, rectifying the long absence of any portrait of Hughes in the King's Hall display, ${ }^{115}$ but shortly after Hughes's death, the

\footnotetext{
107 Anne Gray, Art and Artifice: George Lambert 1873-1930 (Roseville East, NSW: Craftsman House, 1996), 56-57. 108 Gray, Art and Artifice, 56-57.

109 Anne Gray, George Lambert 1873-1930, Catalogue Raisonné: Paintings and Sculpture, Drawings in Public Collections (Perth: Bonamy Press, 1996), 51-52.

110 Evening News (Sydney), 29 January 1915, 4.

111 Punch (Melbourne), 11 February 1915, 13.

112 'In the Public Eye', Observer (Adelaide), 17 January 1925, 35.

113 'Candida', 'Woman's World: Talented Woman Portrait Painter: Marion Jones Passes through Adelaide', News (Adelaide), 18 December 1924, 8-9.

114 George Lambert, 'William Morris Hughes [The Rt Hon William Morris Hughes] 1927', National Gallery of Australia, accessed 24 January 2021, nga.gov.au/exhibition/lambert/detail.cfm?IRN=162224.

115 'Rejected Portrait of Mr Hughes Finally Accepted', Sydney Morning Herald, 26 September 1947, 7.
} 
portrait by Lambert, the more highly regarded painter, took its place. ${ }^{116}$ Lambert's Hughes still hangs in the prime ministerial array in Parliament House, ratifying Walter Benjamin's observation that after a few generations, any portrait is 'no more than a testimony to the art of the person who painted it'. ${ }^{117}$

In his biographical study George Reid (1989), W. G. McMinn mentions neither Lambert's portrait of his subject, nor any other-even Charles Web Gilbert's marble bust, presented to Reid, somewhat unusually, by his Commonwealth Office staff on his retirement in 1916. ${ }^{118}$ The only portrait-related story Reid tells in his own copious memoir My Reminiscences (1917) concerns how he was sometimes mistaken in London for the Scottish portraitist Sir George Reid, president of the Royal Scottish Academy; he recalls the time 'a very distinguished lady paid me a number of charming compliments upon a painting of her husband I had done'. Our Reid was in the United States when the Scotsman died and found 'his American obituary notice dwelt quite as much upon my excellence as a painter as upon the events of my public career'. ${ }^{119}$

\section{A note on the multi-medium memento-set}

This essay has sought to cast doubt on Henry James's poetic fancy of the capacity of portrait painters to see deep into their subjects, undergo them, absorb them, discover in them new things that were not on the surface, 'and, in short, elevate and humanize the technical problem'. Oil portraits are ideological in certain locations, but they are not the only form of portraiture. Perhaps other forms of exhibited media are better suited to conveying something of the biographical subject's interiority. John Berger wrote in the 1960s that he doubted any important portraits in traditional mediums would ever be produced again. However, he could imagine them superseded by 'multi-medium memento-sets devoted to the character of particular individuals'. ${ }^{120}$ What would this look like? The MOAD collection includes a trove of mundane personal objects associated with prime ministers such as a pair of shoelaces, instructions for a rechargeable shaver and some contact lens equipment that were Bob Hawke's; a tie and a bike of Tony Abbott's; and Edmund Barton's Star of the Knight Grand Cross of the Order of St Michael and St George. It has furnishings known to have been handled by prime ministers and is a stakeholder in electronic resources allowing enthusiasts to locate objects such as Ben Chifley's toaster or Joe Lyons's satchel in Australian collections. ${ }^{121}$ Such items can be, and many have been,

116 E. H. Cox, 'Capital Talk: Deadlock Could Last 2 Years', Herald (Melbourne), 24 April 1953, 4.

117 Quoted in Richard Brilliant, Portraiture (London: Reaktion Books, 1991, 1997), 151.

118 W. G. McMinn, George Reid (Carlton, Vic.: Melbourne University Press, 1989).

119 George Reid, My Reminiscences (London: Cassell, 1917), 273, 318.

120 Berger, 'The Changing View of Man in the Portrait', 41.

121 'Australian Prime Ministers', Museum of Australian Democracy, accessed 10 November 2020, primeministers. moadoph.gov.au/collections. 
exhibited among other, diverse material in a biographical 'portrait' of an individual such as the National Archives of Australia's 'multi-medium memento-set' exhibition Stanley Melbourne Bruce: Prime Minister and Statesman in 2009-10, or Sir Edmund Barton: Australia's First Prime Minister, in Parliament House at the time of writing. ${ }^{122}$ Future developments in this kind of exhibit, especially the incorporation of digital video, may prove more illuminating to the political biographer than an oil portrait, as each artefact triggers reflection on an aspect of a personality or career, rather than purporting to encapsulate either. However, such exhibitions demand the input of curatorial, conservation and design personnel, are potentially costly to mount, require a good deal of space and are rarely shown in perpetuity. Even vintage photographs cannot be displayed constantly. There is this to be said for oil portraits: once commissioned, completed, approved and hung, they are no trouble.

\section{Conclusion}

The idea that skilled professional portraitists afford an almost ineffable insight into their subjects' characters is tenacious. Consideration of the circumstances of production of portraits in series, such as successive prime ministerial portraits, may shift public assumptions about the nature and purpose of portraiture. The practicalities of staging a portrait, including the historical moment of its production, will often militate against a portraitist's capacity to reveal the authentic subject, even if they were capable of that in the first place. It is demonstrable that Australian prime ministers' biographers have rarely, if ever, examined oil portraits in an attempt to know their subjects better. Biographers and subjects alike have occasionally favoured portraits by lesser artists over those by artists of higher reputation; occasionally critics have decried outcomes of the HMC commissioning process. Prime ministerial portraits in Australia, like many series of portraits elsewhere, are driven by motives other than showing 'what you were as men to look at'. They fall more often into the category of 'professional apotheosis' than 'intimate interpretation'; even those works that suggest the subject's 'interiority' may be misleading. Prime ministerial portraits have been created for purposes of bolstering and reproducing the public authority of the office itself, of inspiring perceived audiences, and satisfying on the part of the interested public an impulse to 'collect a set'. Recently, the heterogeneity of the Australian prime ministerial set was interrupted by the inclusion of a shiny portrait of the country's first female prime minister, its artist chosen by its subject. Whether or not future biographies of Julia Gillard will refer to that portrait remains to be seen.

122 'Stanley Melbourne Bruce: Prime Minister and Statesman', National Archives of Australia (NAA) AA1970/556, Personal Papers of Prime Minister Bruce; 'Sir Edmund Barton: Australia’s First Prime Minister', Parliament of Australia, accessed 9 April 2021, www.aph.gov.au/Visit_Parliament/Whats_On/News/A_retrospective_exhibition_ of_Sir_Edmund_Barton_life_times_and_Federation. 
This text is taken from Australian Journal of Biography and History: No. 5, 2021, published 2021 by ANU Press, The Australian National University, Canberra, Australia.

doi.org/10.22459/AJBH.05.2021.04 